48 経蝶形骨洞下垂体腫瘍摘出術に対する3D-CT画像の検討 鹿児島市立病院·中央放射線室 太田原美郎，岩元博史，西元辰也 鮫嶋宗俊

【目的】当院では下垂体腫湯に対して経蝶形骨洞手術を行っている. 今回われわれはこれに対する支援画像として3D-CT画像を用い，鼻 中隔，蝶形骨洞，トルコ鞍，下垂体の描出を試みたので報告する。 【方法】上口唇からトルコ鞍に向かう面を中心に50 mm程度の範囲を ヘリカルスキャンし，3D画像の作成を行った．このときの3D画像 は, 術中における顕微鏡下の視野に合わせて鼻中隔, 蝶形骨洞, 卜 ルコ鞍, 下垂体をカラーにて表示した.

【結果および考察】これまでaxial画像をもとに，トルコ鞍や蝶形骨洞 の構造や下垂体腫瘍の形状を評価していた。しかし，今回の3D画像 による鼻中隔，蝶形骨洞，トルコ鞍，下垂体のカラー表示により， 立体的な構造の把握が可能となり顕微鏡下でのアプローチが容易と なった．今後は，今回の画像をさらに精細に表示することにより内 視鏡下経鼻的下垂体手術におけるナビゲーションシステムとして応 用できるものと考える.

\section{9 外傷時におうける椎体CT-MPRの有用性の検討}

聖マリアンナ医科大学横浜市西部病院 立石貴代子，宮崎寿哉

辻村栄美，森 寿一，岩瀬雅則，楠本伸弥

【目的】椎体骨折や春髄損傷が疑われる外傷受傷時において, 椎体の sagittal画像は診断に重要視されている. 今回われわれは, 緊急CT検查時における椎体のMPR (multiplanar reconstruction)を用いたsagittal 画像の有用性の検討を行った。

【方法】椎体骨折や脊髄損傷を伴う(または疑われる)症例に対して脊 椎CTを施行LMPR画像とCT-axial画像および単純X-P画像との比較 検討を行った。

【結果】脊椎骨折はCT-axial画像で評価できるが，MPRを付加するこ とにより骨折部位とその周辺構造の関係がより明瞭となった．特に 骨片の脊柱管内への变位の程度の評価はaxial画像のみでは困難な場 合があり，MPR画像は有用であると思われた。また単純X-P画像で は下部頸椎から上部胸椎が描出困難な場合が多く, MPRで得られる sagittal画像の有用性が示唆された。

【考察】多発外傷受傷時では被検者の体位が制限され，単純X-P撮影 において下部頸椎から上部胸椎の側面画像の情報が得られない場合 が多くある。しかし同時に行われる全身の緊急CT検查において得ら れるMPRを用いた椎体のsagittal画像は，単純X-Pにて描出困難な部 位も観察可能となり有用性があると思われた。

\section{0 低位埋伏下顎智歯の抜去時におけるCT画像情報の有用性}

国家公務員共済組合連合会立川病院・放射線科山田 稔

【目的】下顎智歯が低位埋伏している場合，下顎管との位置関係がし ばしば問題となる。つまり下顎管の内部には下歯槽神経や下歯槽動 静脈が走行しており, 抜歯の際, それらを損傷・断裂させてしまう 危険性があるためである。そこでわれわれはCT拉よびWork Station を用いて下顎智歯と下顎管との位置関係を三次元的に示し, 臨床に 役立つ情報を提供できたので報告する。

【方法】パントモグラフィを撮影し，下顎智歯と下顎管が近接してい ると疑われたものに対してCTを施行した，そしてWork Stationを用 いて3D画像・MPR画像を作製し，下顎智歯と下顎管の位置関係を示 した。

【考察・結果】3D画像は視覚的に立体的なものとしてとらえることが でき，重なり合ったものの前後関係を容易に理解できる点で有用で ある. またMPR画像は任意の断面から必要な断面の画像を抽出でき る点で有用である．実際臨床例と照らし合わせてみると，下顎智歯 と下顎管の位置関係を正確に示していることが分かった。
51 口腔領域におけるディジタルX線写真のピクセルサイズ最適 化一第 1 報 スキャナの特性についてー

広島大学藏学部 隅田博臣, 大塚昌彦/名古屋大学 小寺吉衞 日本大学 丸橋一夫/大阪大学 角田 明/九州大学 加藤 誠 鹿児島大学 西郷康正/九州大学 大喜雅文

【目的】昨年の総会にてデンタル撮影におけるディジタル化のための サンプリングについて, 広島大学歯学部単独での実験を行い報告を 行った. 今回は 5 大学歯学部合同で実験を行うのに際し, 画像の データベース作成を行った，その時に使用するスキャナの選択なら びに取り込み条件を決定するため，3 種類のスキャナの特性を調べ た．第 2 報でその結果を基にROC評価を行った報告をする。

【方法】試料として金属ステップをX線撮影した後，3 種類のスキャ ナを用いスキャンした，その画像をNIH Imageソフトにより，画像 上にROIのデイジタル值(ピクセル值)を求め, 濃度vsピクセル值の 関係を調べた。

【結果】どのスキャナも再現性に関しては良好であった。濃度vsピク セル值の関係は, スキャナの取り込み条件で変化した.

【結論】ROC評価を行うためのスキャナの選択と画像の取り込み条件 を決定した。

52 口腔領域におけるディジタルX線写真のピクセルサイズ最適 化一第 2 報 ROC評価についてー

広島大学蒾学部 隅田博臣, 大塚昌彦/名古屋大学 小寺吉衞 日本大学 丸橋一夫/大阪大学 角田 明/九州大学 加藤 誠 鹿児島大学 西鄉康正/九州大学 大喜雅文

【目的】第 1 報のスキャナの特性を基に 5 大学歯学部合同によるROC 評価を行ったので報告する。

【方法】5大学より隣接面カリエス 1 の臨床的裏づけのとれた写真を 計百数十症例集めた，そのうち，歯科放射線科医にてデンタル写真 を確認し，C1以外また 2 隣接面以上にカリエスがあると判断，もし くは疑いのある写真は排除した。その結果，28症例のC1ありとノー マル37症例，合計 65 症例のデンタル写真をデータベースとして使用

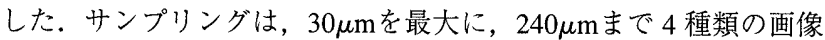
データを作成した。観察は最低 2 週間のインターバルを設け，画素 サイズの大きいデータより観察した。観察方法はSMPTEパターンに てコントラスト輝度を調節した17インチCRTを使用し, 暗室環境に て行った。観察者は，5大学歯学部の歯科放射線科医および小児歯 科医計20名で，連続確信度によるROC評価を行った。

【結果】前回の結果同様，100 $\mu \mathrm{m}$ 付近でROCのAzは飽和すると思われ る.

【考察】5大学による実験で診断における大学の偏りが除去でき, データとしての信頼性が向上したと考えられる。

\section{3 モニ夕観察における胸部CR画像の縮小・圧縮の検討}

広島大学医学部附属病院 ·放射線部 池田俊貴, 古川隆志, 安部伸和 大石康子，玖島利男/富士フイルムメディカル(株) 石川貴洋 横河電機(株) 栗山 滋

【目的】現在, 当院におけるCR画像診断は, フィルムおよびCR専用 モニ夕併用で行っている，画像診断は，フィルムからモ二夕診断へ 移行しようとしているが, 各診療科, 病棟等に多数の高精細モ二夕 を設置するには，経済的に困難である。また画像は，放射線部のCR 画像サーバからHIS側の画像管理サーバを通して，それぞれ配信さ れるが, HIS側のサーバ容量に限度があるため, 生画像の配信は困 難である。そこで, 胸部CR画像のモニ夕観察で画像の縮小・圧縮が 視覚的に及ぽす影響について検討を行った。

【方法】1)可逆圧縮された胸部CR画像をCR画像サーバより解凍し, ICR-1サーバにて1/4および1/16の縮小画像を作成する. (2)(1)で縮小 された画像をJPEG圧縮率を変化させて数種類の画像を作成する. 